\title{
Prevalence of intestinal parasites versus knowledge, attitudes, and practices of inhabitants of low-income communities of Campos dos Goytacazes, Rio de Janeiro State, Brazil
}

\author{
Antonio Henrique A. de Moraes Neto • Adriana P. M. F. Pereira • \\ Maria de Fátima L. Alencar • Paulo R. B. Souza-Júnior • Rodrigo C. Dias • \\ Juliana G. Fonseca • Clóvis P. Santos • João C. A. Almeida
}

Received: 15 December 2009 / Accepted: 26 March 2010/Published online: 21 April 2010

(C) Springer-Verlag 2010

\begin{abstract}
Intestinal parasites are the causative agents of common infections responsible for significant public health problems in developing countries and generally linked to lack of sanitation, safe water, and improper hygiene. More than two billion people throughout the world live with unrelenting illness due to intestinal parasitic infections (IPIs). The purposes of this study are to assess knowledge, attitudes, and practices on IPIs and investigate the relationship with prevalence of intestinal parasites among a lowincome group of inhabitants from two communities of the Travessão District area, Campos dos Goytacazes, north of
\end{abstract}

Acknowledgments of funding This work was supported by Fundação Oswaldo Cruz (FIOCRUZ), Conselho Nacional de Desenvolvimento Científico e Tecnológico (MCT-CNPq), Fundação Carlos Chagas Filho de Amparo à Pesquisa do Estado do Rio de Janeiro (FAPERJ) (grants E-26/170.711/2007 and E-26/100.226/ 2009), and Pró-Reitoria de Extensão e Assuntos Comunitários (PROEX) da Universidade Estadual do Norte Fluminense Darcy Ribeiro (UENF).

A. H. A. de Moraes Neto $(\bowtie) \cdot$ A. P. M. F. Pereira • M. L. Alencar Laboratório de Ecoepidemiologia e Controle da Esquistossomose e Geohelmintoses, Instituto Oswaldo Cruz,

Fundação Oswaldo Cruz,

21045-900 Rio de Janeiro, Brazil

e-mail: ahmn@ioc.fiocruz.br

P. R. B. Souza-Júnior

Laboratório de Informação em Saúde, Instituto de Comunicação

e Informação Científica e Tecnológica em Saúde,

Fundação Oswaldo Cruz,

21045-900 Rio de Janeiro, Brazil

R. C. Dias

Laboratório de Pesquisas Clínicas Plínio Bacelar,

28010-076 Campos dos Goytacazes,

Rio de Janeiro, Brazil
Rio de Janeiro State, Brazil. The two communities are known as "Parque Santuário," which is an urban slum with miserable living conditions, and "Arraial," where the socioeconomic and educational levels are better, neither having a sanitary infrastructure with an excreta collection system. Questionnaires revealed that both communities had local and specific codification to denominate the intestinal parasites and present correct knowledge on the theme but ignored some aspects of IPI transmission, with the Arraial population being better informed $(p<0.05)$. The overall prevalence of IPIs in

J. G. Fonseca • J. C. A. Almeida

Laboratório de Fisiologia e Bioquímica de Microorganismos, Centro de Biociências e Biotecnologia,

Universidade Estadual do Norte Fluminense Darcy Ribeiro (UENF),

28013-602 Campos dos Goytacazes,

Rio de Janeiro, Brazil

\section{P. Santos}

Laboratório de Biologia Celular e Tecidual,

Centro de Biociências e Biotecnologia,

Universidade Estadual do Norte Fluminense Darcy Ribeiro

(UENF),

28013-602 Campos dos Goytacazes,

Rio de Janeiro, Brazil 
Parque Santuário (49.7\%) was greater than in Arraial $(27.2 \%)(p<0.001$; prevalence ratio/95\% confidence interval 1.83/1.50-2.23). This study reports the real IPI situation in the Travessão District and also reinforces the need to continue the investigation on the impact of combined prophylactic methods, educational measures, and socioeconomic and sanitary improvements by governmental authorities and the local popular organization.

\section{Introduction}

Intestinal parasites are the causative agents of common infections responsible for significant public health problems in developing countries, and more than two billion people throughout the world live with unrelenting illness due to intestinal parasitic infections (IPIs) (Dagci et al. 2008; WHO 2005a). Parasitic infections are associated with lack of sanitation and access to safe water, depriving poor populations of health and well-being and contributing to social marginalization through economic progress prevention (Mehraj et al. 2008; WHO 2005a). Approximately 300 million people suffer severe morbidity associated with these parasites, at least $50 \%$ of which are school-age children affected by massive infections (Keiser and Utzinger 2008). IPIs rarely lead to death, but because the problem is widespread, the global number of related deaths is substantial (WHO 2004, 2005a). About 39 million people lose years of productivity due to disability adjusted life years from IPIs, thus representing a formidable economic burden (Stephenson et al. 2000).

Ascaris lumbricoides, Trichuris trichiura, and hookworms, collectively referred to as soil-transmitted helminths (STHs), are the most common intestinal parasites (Bethony et al. 2006). A. lumbricoides is the largest and most frequent helminth parasitizing the human intestine, currently infecting about one billion people worldwide (CDC 2006). Giardia lamblia, the most prevalent protozoan parasite worldwide with about 200 million people currently infected (Pillai and Kain 2003; Minenoa and Avery 2003), has been increasingly worrying public health authorities since the emergence of strains resistant to conventional therapeutic agents (SVS 2005). Approximately $10 \%$ of the world population is infected by Entamoeba histolytica, $90 \%$ of which are asymptomatic (Reed 2001). Of the roughly 50 million symptomatic cases each year, up to 100,000 are fatal (Kucik et al. 2004).

Several health education programs have been developed based on knowledge, attitudes, and practices (KAP) in low-income communities to prevent and reduce IPIs (Omoigberale and Airauhi 2006; Garg et al. 2002). These programs take advantage of the school environment as an operational basis, possess low cost-effectiveness, and encourage public involvement, instigating change in habits resulting in healthy behavioral practices (WHO 2005b; Mascie-Taylor et al. 2003; Montresor et al. 2002). Consequently, instructed teachers and students can function as disseminators of information on health habits within their community, therefore contributing to endemic disease control (Uchôa et al. 2004).

Deworming has made impressive advances in the realm of public health. Millions of people, especially school-age children, have gained access to affordable, effective antihelminthic drugs, which has resulted in improved health and well-being. Progress has been so evident that in May 2001, the 54th Session of the World Health Assembly (WHA) adopted Resolution WHA 54.19. The prevailing deworming strategy was endorsed, member states were urged to intensify control activities, and the United Nations organizations together with bilateral agencies were encouraged to intensify support for control activities. The Resolution also asked the director-general of the World Health Organization (WHO) to expedite the formation and work of partnerships for the control of schistosomiasis and STHs in high transmission areas. The Resolution WHA 54.19 goals are, in the short-term, to reduce morbidity through drug access (praziquantel and broad-spectrum anthelminthics), implement good case management in all health services, and offer regular treatment to at least $75 \%$ of school-age children by 2010, targeting other high-risk groups (young children, women of childbearing age, occupational groups) through existing public health programs and channels (WHO 2005a). In addition, the 49th Directing Council at the 61st Session of The Regional Committee establishes that efforts must be employed to go forward in eliminating or at least reducing the burden of neglected and poverty-related diseases by 2015 , especially with regard to STHs in Latin America and the Caribbean, where 13 of the 14 countries, according to available information, present at least one area with an STH prevalence higher than 20\% (WHO 2009).

Previous studies (Barçante et al. 2008; Bóia et al. 2006; Ferreira and Andrade 2005) in several Brazilian lowincome communities have exhibited diverse prevalence rates of IPIs. These variations occur with respect to sanitation levels and the cultural characteristics of the analyzed populations. More IPIs are found in rural zones and the peripheries of major cities (Bencke et al. 2006). Detrimental sociocultural influences within these populations would include lack of education, personal hygiene, and nutritional habits; absence of proper plumbing facilities; overcrowding in homes; indiscretion in contact with animals; and inadequate refuse disposal (Gamboa et al. 1998). The purpose of this study is both to assess the KAP related to IPIs among inhabitants in the low-income communities of Travessão District area, Campos dos 
Goytacazes, north of Rio de Janeiro State, Southeastern Brazil, and investigate whether or not there is any relationship between these features and the prevalence of intestinal parasites in this area.

\section{Materials and methods}

\section{Studied area and population}

The Travessão District is located $18 \mathrm{~km}$ from the downtown of Campos dos Goytacazes, located in the north of Rio de Janeiro State, Southeastern Brazil $\left(21^{\circ} 35^{\prime} 52^{\prime \prime} \mathrm{S}, 41^{\circ} 19^{\prime} 3^{\prime \prime} \mathrm{W}\right)$ (Fig. 1). The average annual temperature, relative humidity, and precipitation from 2004 to 2008 were $22.9^{\circ} \mathrm{C}, 80.1 \%$, and $1,186.5 \mathrm{~mm}$, respectively, according to data obtained from the Empresa de Pesquisa Agropecuária (PESAGRO), Campos dos Goytacazes, RJ, Laboratório de Engenharia Agrícola (LEAG)/UENF, weather station. The population is 18,000 people, distributed in higher density in the urban center than the rural areas (IBGE 2009). In this study, samples obtained from two neighborhoods (with approximately 3,000 inhabitants each) within the urban area of Travessão were analyzed: (i) "Parque Santuário" (PS: $21^{\circ} 36^{\prime} 54^{\prime \prime} \mathrm{S}, 41^{\circ} 18^{\prime} 37^{\prime \prime} \mathrm{W}$ ) presented aspects of an urban slum with miserable living conditions; muddy, unpaved streets; and dwellings of which for the most part are improvised with minimum comfort (Fig. 2a-c); and (ii) "Arraial" (AR: $21^{\circ} 36^{\prime} 2^{\prime \prime} \mathrm{S}, 4^{\circ} 18^{\prime} 49^{\prime \prime} \mathrm{W}$ ) exhibited better conditions with paved and illuminated streets and domiciles of solid and lasting construction involving standard building materials such as timber, concrete, and brick (Fig. 2e, f). However, neither community possessed sanitary infrastructure with a city sewage system. The water supply was from superficial wells (Fig. 2d) exposed to environmental contamination from septic tanks (Costa and Alves 2007). In both communities, there was periodic garbage collection.

\section{Survey of resident socioeconomic conditions}

The socioeconomic data were obtained in a questionnaire on number of people per household, age, education, income, domicile characteristics, drinking water, and garbage collection.

Collection and processing of KAP for IPIs and fecal sample data

The data acquisition was obtained through the application of questionnaires of Mello et al. (1988) for the parents or legal responsible persons (respondents) of each of the families studied (AR $n=177$ and PS $n=258$ ) and was aimed at identifying the KAP of inhabitants of both

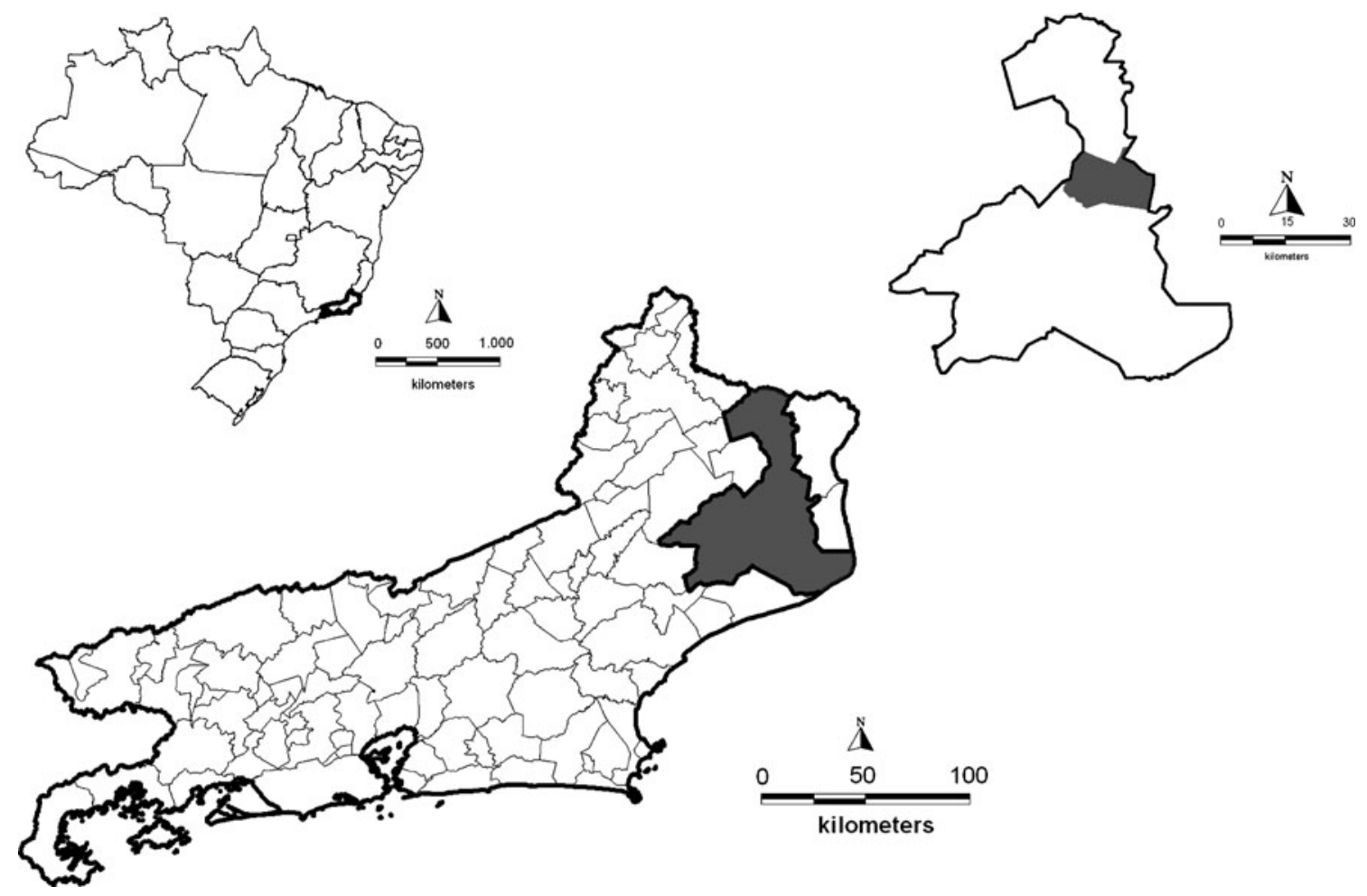

Fig. 1 Localization of Travessão District in Campos dos Goytacazes, Rio de Janeiro State, Brazil 
Fig. 2 a-f Overview of PS and $\mathrm{AR}$ communities from Travessão District, Campos dos Goytacazes, Rio de Janeiro State, Brazil. a-c PS community: the streets are unpaved and muddy; there is no urban sewage system and no regular garbage collection. The dwellings are, for the most part, improvised and of flimsy, makeshift materials affording only a bare minimum of comfort and protection from the elements. d The water is supplied obtained from superficial wells exposed to environmental contamination from faulty septic tanks of neighboring habitations in both communities. e-f AR community: the streets were paved and illuminated. The dwellings were of solid and lasting construction involving standard building materials such as timber, concrete, and brick
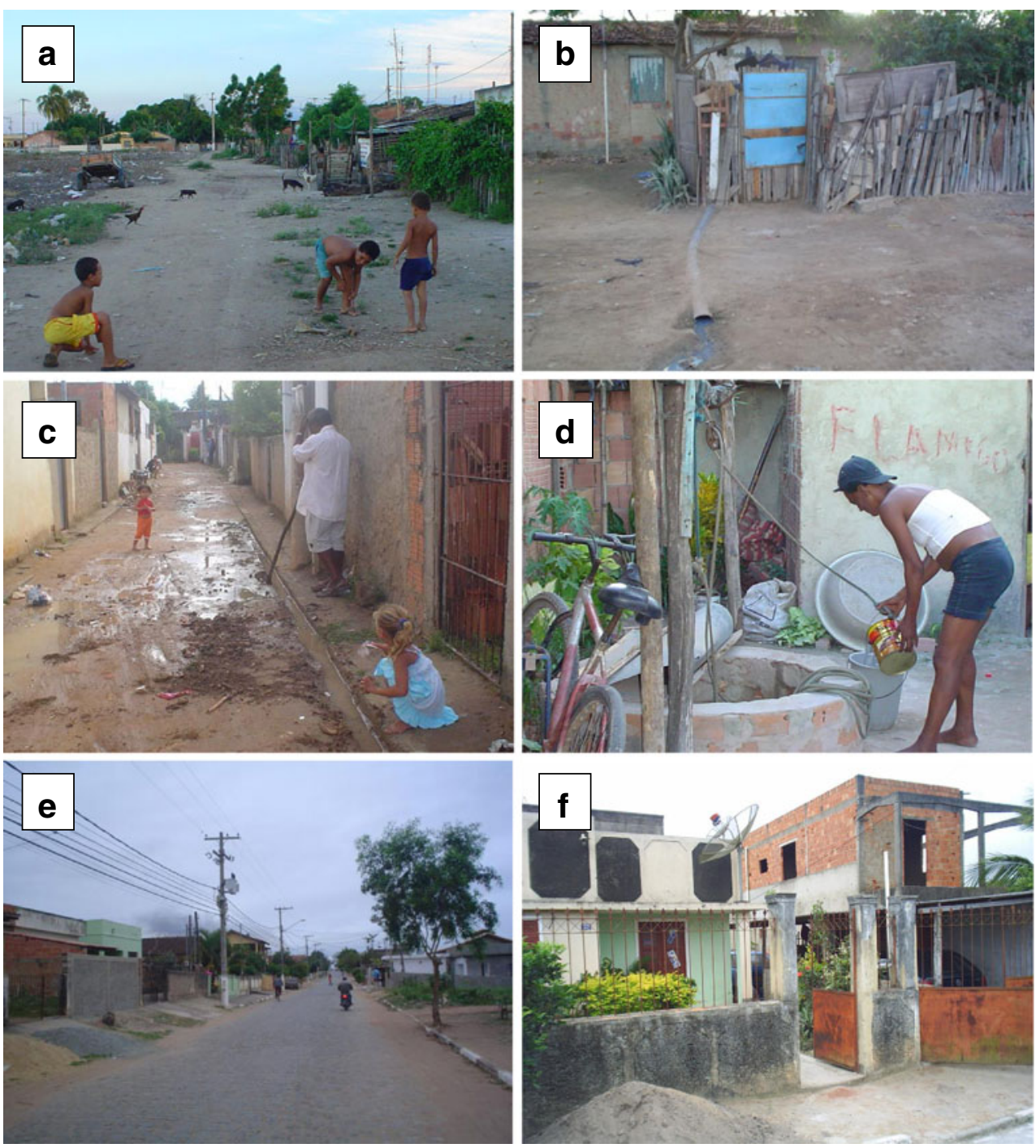

communities concerned with IPIs. All residences situated in these communities were visited, and a census for IPIs performed.

The questionnaire answers were categorized according to concepts of parasitology adopted by Rey (2002) in correct, partly correct, incorrect, and unknown (quantitative analysis) and by answer frequency. The fecal material collection was performed in the domiciles, which were visited by students and researchers from "Programa Parasitoses do Norte Fluminense" of the "Universidade Estadual do Norte Fluminense" and from the "Laboratório de Ecoepidemiologia e Controle da Esquistossomose e Geohelmintoses," "Instituto Oswaldo Cruz," FIOCRUZ. Three hundred sixteen individuals from PS in 2004 and 2005 and 375 from AR in 2008 returned fecal samples for this study. The samples were analyzed through sedimentation procedure (Lutz 1919) by experienced laboratory technologists from "Laboratório Regional de Patologia Clínica" ("Hospital Geral de Guarús") and "Laboratório de Análises Clínicas Plínio Bacelar", both with ISO 9001 certification.
Water analysis

The presence of coliform group bacteria in water samples is considered by the WHO (2006a) as a parameter for water quality evaluation. WHO does not determine a rigid criteria for the classification of human consumption potability because these criteria are subject to present regional variation. In Brazil, the Ministry of Health regulates the pattern of water potability for human consumption by ordinance 518/2004, which stipulates that water quality must be evaluated by the presence of total and thermotolerant coliform, preferably Escherichia coli, and both must be absent from a 100-ml sample (MS 2004). Water samples were randomly taken from residences that utilized water from superficial wells for consumption. Samples from 31 wells in the PS community and 5 in AR were analyzed using the multiple-tube technique (APHA 1998). Samples were collected in sterile flasks, kept in ice, and analyzed up to 2 hours afterwards. In the multiple-tube fermentation technique, samples are inoculated in lactose broth (pre- 
sumptive test for coliform bacteria group). Positive samples are inoculated in brilliant Green bile 2\% broth (confirmative test for total coliform) and EC broth for detection of $E$. coli bacteria. Coliform bacteria are gramnegative, non-spore-forming rods that ferment lactose with acid and gas formation after 48 hours at $35^{\circ} \mathrm{C}$. They include the genera Klebsiella, Enterobacter, Citrobacter, and Escherichia from the Enterobacteriaceae family and are usually considered as indicators for water contamination. Fecal coliform bacteria are a subset of the total coliform group that proliferate at $44.5^{\circ} \mathrm{C}$ and are capable of limited survival and growth in the environment, being considered indicative for fecal contamination in water.

Treatment of parasited individuals

The drugs in the treatment were provided by Farmanguinhos, FIOCRUZ, and by the public health authorities of Campos dos Goytacazes. Every parasited individual in this survey was home-treated by physicians of the Programa Parasitoses do Norte Fluminense. Treatment protocol was as follows: individuals parasited by STHs were given orally, under supervision, two $100 \mathrm{mg}$ doses per day of mebendazole for 3 days, repeated after 10 days, whereas for protozoan infections (giardiasis and amoebiasis), three $250 \mathrm{mg}$ doses per day of metronidazole were administered for 7 days. Individuals with mixed infections were formerly treated with mebendazole and later with metronidazole. Pregnant women and those with amenorrhea were excluded from the survey.

\section{Data management and statistical analysis}

During data collection, completed questionnaires were checked regularly to rectify any discrepancy or missing values. Data from questionnaires and water analysis were entered in an EXCEL datasheet, and data from stool examinations by ACCESS (Microsoft Office 2007 for Windows) and then exported to Epiinfo version 3.5.1 and to Statistical Package for the Social Sciences (SPSS) version 15.0, respectively, for statistical analysis.

The chi-square test was used to verify associations. The level of statistical significance was set as $p<0.05$, and for each statistically significant factor, a prevalence ratio (PR) and $95 \%$ confidence interval (CI) was computed.

Strengths and limitations

As to our knowledge, this is the first study in low-income areas of Campos dos Goytacazes, Rio de Janeiro, Brazil. The stool sample tested by a routine ova and parasite method in conjunction with a concentration technique increased the validity of the estimates. Some individuals absent or refusing to cooperate was a limitation that must be considered for result interpretation. In PS, the refusals corresponded to $14 \%$ of the total residences, whereas in AR, the percentage was much greater, 55\%. This high index of refusals in AR was due to these individuals declaring they had private health plans. Another interference is that not all respondents gave their feces, which reduced the sample size and decreased the precision of the estimates. In water analysis, few samples were collected because of the proximity of the collection points, considering that all wells in the region were superficial, therefore most probably sharing the same ground water.

\section{Ethics}

Every family was recruited for the survey following signature of a standard consent form by the legally responsible person. The protocol of this research was approved by FIOCRUZ Committee for Ethics on Research (Protocol Number 404/07).

\section{Results}

The educational and socioeconomic status with other features of community residents are shown in Table 1.

In most water samples analyzed, the presence of total bacteria extrapolates the sensitivity of the technique (Table 2) in both presumptive and confirmative tests, indicating that water of both communities is improper for human consumption and highly contaminated. E. coli, an indicative of fecal contamination, was detected in all five AR samples and $60 \%$ of the 31 PS samples.

Concerning questionnaire answers on KAP related to IPIs, in Table 3, there are data related to parasite life cycles, and in Table 4, etiology, life cycles, diagnostics, and symptomology. The respondents of the AR community displayed better knowledge on IPIs $(p<0.05$, to the majority of issues), and about half of the PS respondents (47.3\%) admitted ignorance concerning this subject (Table 4). The populations of both communities had their own codifications for the intestinal parasites, most frequent being "lombriga," "giardia," "solitária," or "tenia."

The most common symptoms described by the respondents in both communities (AR and PS) were bellyache (AR= $33.3 \%, \mathrm{PS}=27.9 \%)$, nausea $(\mathrm{AR}=19.2 \%, \mathrm{PS}=17.0 \%)$, and vomiting $(\mathrm{AR}=18.6 \%, \mathrm{PS}=16.7 \%)$. They also related the habit of spiting frequently and eating clay brick and sweets, associated with harboring parasites. With respect to treatment, most $(\mathrm{AR}=84.2 \%, \mathrm{PS}=88.4 \%)$ sought medical attention, both doctor or health center, and used antiparasitic medication $(\mathrm{AR}=75.7 \%, \mathrm{PS}=53.9 \%)$. As alternative treatments, home remedies were mentioned such as mint tea (Mentha sp, with 
Table 1 Socioeconomic profile of residents from AR and PS communities located in

Travessão District, Campos dos Goytacazes, Rio de Janeiro, Brazil
$\operatorname{AR}(n=177)$ and PS $(n=258)$.

${ }^{\mathrm{a}} \mathrm{MSM}=$ minimum monthly salary: 1 minimum salary is the least that a worker can receive monthly in a regular job in Brazil, established by government (corresponds to US\$ 247. 27, $\mathrm{R} \$ 465.00)$.

\begin{tabular}{|c|c|c|c|}
\hline Aspect evaluated & Answer & AR $(\%)$ & PS $(\%)$ \\
\hline \multirow[t]{3}{*}{ Age Bracket } & 0 to 9 & 16.8 & 22.8 \\
\hline & 10 to 19 & 23.8 & 19.9 \\
\hline & $\geq 20$ & 59.4 & 57.3 \\
\hline \multirow[t]{2}{*}{ Gender } & Male & 50.6 & 49.7 \\
\hline & Female & 49.4 & 50.3 \\
\hline \multirow[t]{7}{*}{ Scholarity } & Illiterate & 17.7 & 12.9 \\
\hline & Incomplete elementary school & 61.6 & 74.4 \\
\hline & Complete elementary school & 1.6 & 0.0 \\
\hline & Incomplete high school & 9.2 & 4.2 \\
\hline & Complete high school & 8.8 & 8.1 \\
\hline & Incomplete higher education & 0.4 & 0.0 \\
\hline & Complete higher education & 0.7 & 0.4 \\
\hline \multirow[t]{3}{*}{ Monthly income } & Less than $1 \mathrm{MSM}^{\mathrm{a}}$ & 2.2 & 4.9 \\
\hline & $1 \mathrm{MSM}$ & 38.1 & 45.9 \\
\hline & 2 to $4 \mathrm{MSM}$ & 59.7 & 49.2 \\
\hline \multirow[t]{3}{*}{ Resident $\mathrm{n} /$ Domicile } & 1 to 3 & 41.0 & 92.6 \\
\hline & 4 to 6 & 47.8 & 3.3 \\
\hline & 7 to 13 & 11.2 & 4.1 \\
\hline \multirow[t]{2}{*}{ Water for human consumption } & Supplied by public water treatment plant & 26.9 & 73.2 \\
\hline & Mineral water & 73.1 & 26.8 \\
\hline \multirow[t]{3}{*}{ Habitation } & Proprietary & 92.6 & 92.6 \\
\hline & Rented & 5.2 & 3.3 \\
\hline & Property of others & 2.2 & 4.1 \\
\hline \multirow[t]{3}{*}{ Floor } & Wood & 0.0 & 0.8 \\
\hline & Ceramic & 75.4 & 63.4 \\
\hline & Concrete & 24.6 & 35.8 \\
\hline \multirow[t]{2}{*}{ Wall } & Bricks without rendering & 14.2 & 21.1 \\
\hline & Bricks with rendering & 85.8 & 78.9 \\
\hline \multirow[t]{2}{*}{ Toilet } & Don't have & 2.2 & 0.8 \\
\hline & Have & 97.8 & 99.2 \\
\hline \multirow[t]{2}{*}{ Garbage discard } & Public collection & 100.0 & 96.7 \\
\hline & Vacant & 0.0 & 3.3 \\
\hline
\end{tabular}

Table 2 Occurrence of total coliform (bacteria group) and fecal coliform in AR and PS communities located in Travessão District, Campos dos Goytacazes, Rio de Janeiro, Brazil

\begin{tabular}{|c|c|c|c|c|c|c|c|c|c|c|c|c|c|c|}
\hline \multirow[t]{2}{*}{ Test } & \multicolumn{7}{|l|}{ AR } & \multicolumn{7}{|l|}{ PS } \\
\hline & $<1.1$ & 2.2 & 6.9 & 12 & 16 & 23 & $>23$ & $<1.1$ & 2.2 & 6.9 & 12 & 16 & 23 & $>23$ \\
\hline Presuntive test for total coliform ${ }^{a}$ & - & - & - & - & - & 1 & 3 & - & - & - & - & - & - & 29 \\
\hline Confirmative test for total coliform ${ }^{\mathrm{a}}$ & - & - & - & - & - & 2 & 2 & - & - & 1 & 1 & - & 3 & 24 \\
\hline Fecal coliform ${ }^{\mathrm{b}}$ & - & - & - & - & 1 & 3 & - & 9 & 1 & 1 & 1 & 3 & 2 & 12 \\
\hline
\end{tabular}

Results are expressed as most probable number of bacteria present in a 100-ml sample, measured by considering the number of positive samples in $10 \times 10$-ml tubes.

${ }^{\mathrm{a}}$ Number of positive tubes in $10 \times 10$-ml tubes.

${ }^{\mathrm{b}}$ Most Probable Number of bacteria present per $100-\mathrm{mL}$ sample. 
Table 3 Frequency of the multiple answers to the questionnaire on knowledge of inhabitants of AR and PS communities located in Travessão District, Campos dos Goytacazes, Rio de Janeiro, Brazil, concerning some aspects of the life cycle of the intestinal parasites

\begin{tabular}{|c|c|c|c|c|c|}
\hline \multirow[t]{3}{*}{ Evaluated aspect } & \multirow[t]{3}{*}{ Answers } & \multicolumn{4}{|c|}{ Families number } \\
\hline & & \multicolumn{2}{|l|}{$\mathrm{AR}$} & \multicolumn{2}{|l|}{ PS } \\
\hline & & $n$ & $\%$ & $n$ & $\%$ \\
\hline \multirow[t]{10}{*}{ Infection source } & Barefooted & 66 & 37 & 92 & 36 \\
\hline & Foods unwashed & 47 & 27 & 44 & 17 \\
\hline & Unknown & 43 & 24 & 76 & 29 \\
\hline & Contaminated water & 34 & 19 & 32 & 12 \\
\hline & Unclean hands & 30 & 17 & 27 & 10 \\
\hline & Sand & 22 & 12 & 34 & 13 \\
\hline & Hygiene lack & 14 & 8 & 21 & 8 \\
\hline & Sweets & 11 & 6 & 28 & 11 \\
\hline & Garbage & 9 & 5 & 4 & 2 \\
\hline & Other forms & 24 & 14 & 42 & 16 \\
\hline \multirow[t]{7}{*}{ Site of infection } & Unknown & 60 & 34 & 139 & 54 \\
\hline & Feet & 34 & 19 & 37 & 14 \\
\hline & Mouth & 31 & 18 & 18 & 7 \\
\hline & Food & 30 & 17 & 24 & 9 \\
\hline & Skin & 18 & 10 & 10 & 4 \\
\hline & Unclean hands/nails & 21 & 12 & 21 & 8 \\
\hline & Other forms & 36 & 20 & 46 & 18 \\
\hline \multirow[t]{11}{*}{ Habitat in human body } & Gut & 66 & 37 & 77 & 30 \\
\hline & Unknown & 38 & 21 & 55 & 21 \\
\hline & Abdomen & 31 & 18 & 74 & 29 \\
\hline & Stomach & 18 & 10 & 27 & 10 \\
\hline & Blood & 16 & 9 & 14 & 5 \\
\hline & Liver & 15 & 8 & 17 & 7 \\
\hline & Stool & 6 & 3 & 5 & 2 \\
\hline & Anus & 5 & 3 & 5 & 2 \\
\hline & Migration in the body & 5 & 3 & 5 & 2 \\
\hline & Skin & 2 & 1 & 4 & 2 \\
\hline & Other forms & 16 & 9 & 17 & 7 \\
\hline \multirow[t]{10}{*}{ Ways of elimination and place of deposition of the parasites } & Unknown & 88 & 50 & 163 & 63 \\
\hline & Stool & 28 & 16 & 19 & 7 \\
\hline & Gut & 13 & 7 & 21 & 8 \\
\hline & Abdomen & 7 & 4 & 15 & 6 \\
\hline & Sewage & 6 & 3 & 6 & 2 \\
\hline & Anus & 4 & 2 & 1 & 0 \\
\hline & Blood & 2 & 1 & 9 & 3 \\
\hline & Liver & 2 & 1 & 6 & 2 \\
\hline & Stomach & 2 & 1 & 3 & 1 \\
\hline & Other forms & 27 & 15 & 26 & 10 \\
\hline \multirow[t]{4}{*}{ Survival of the parasite in the interior of the organism } & Survive & 126 & 71 & 180 & 70 \\
\hline & Unknown & 20 & 11 & 28 & 11 \\
\hline & Not survive & 11 & 6 & 23 & 9 \\
\hline & Other forms & 10 & 6 & 29 & 11 \\
\hline \multirow[t]{5}{*}{ Survival of the parasite out of the body } & Unknown & 75 & 42 & 145 & 56 \\
\hline & Die & 61 & 34 & 70 & 27 \\
\hline & Live & 7 & 4 & 13 & 5 \\
\hline & Pass to another person & 12 & 7 & 5 & 2 \\
\hline & Other forms & 18 & 10 & 27 & 10 \\
\hline
\end{tabular}

$\operatorname{AR}(n=177)$ and PS $(n=258)$. 
Table 4 Quantitative analysis of answers to the questionnaire questions of inhabitants of AR and PS communities located in Travessão District, Campos dos Goytacazes, Rio de Janeiro, Brazil, about KAP related to IPIs

\begin{tabular}{|c|c|c|c|c|c|c|c|c|}
\hline \multirow{2}{*}{$\begin{array}{l}\text { Questions } \\
\text { Status (\%) }\end{array}$} & \multicolumn{4}{|l|}{$\mathrm{AR}$} & \multicolumn{4}{|l|}{ PS } \\
\hline & Correct & Parcially Correct & Wrong & Unknown & Correct & Parcially Correct & Wrong & Unknown \\
\hline What do you know about IPIs?* & 69.4 & 3.4 & 4.0 & 23.2 & 39.1 & 7.4 & 6.2 & 47.3 \\
\hline What causes IPIs?* & 48.6 & 7.3 & 13.6 & 30.5 & 27.9 & 9.7 & 24.4 & 38.0 \\
\hline How do you acquire IPIs? & 64.4 & 5.6 & 4.0 & 26.0 & 54.2 & 10.5 & 5.8 & 29.5 \\
\hline Where do you acquire IPIs?* & 53 & 1.1 & 9.0 & 36.7 & 43.5 & 3.1 & 5.0 & 48.4 \\
\hline $\begin{array}{l}\text { How do intestinal parasites infect } \\
\text { human beings? }\end{array}$ & 57.1 & 1.1 & 6.2 & 35.6 & 39.1 & 3.1 & 3.9 & 53.9 \\
\hline $\begin{array}{l}\text { Where do intestinal parasites lodge } \\
\text { after infection? }\end{array}$ & 74.6 & 1.1 & 2.3 & 22.0 & 74.8 & 2.7 & 1.2 & 21.3 \\
\hline $\begin{array}{l}\text { What is the destiny of the worms } \\
\text { inside a person?* }\end{array}$ & 23.7 & 5.1 & 26.0 & 45.2 & 10.9 & 5.0 & 28.3 & 55.8 \\
\hline Where do the worms go?* & 42.4 & 1.7 & 2.8 & 53.1 & 20.5 & 10.9 & 5.4 & 63.2 \\
\hline $\begin{array}{l}\text { How long do intestinal parasites survive } \\
\text { in the body? }\end{array}$ & 74.6 & 1.1 & 13.0 & 11.3 & 74.0 & 2.7 & 12.4 & 10.9 \\
\hline $\begin{array}{l}\text { What happens with the intestinal } \\
\text { parasites out of the body? }\end{array}$ & 46.8 & 2.3 & 6.8 & 44.1 & 32.1 & 1.2 & 10.5 & 56.2 \\
\hline What does the person feel when he has worms? & 82.4 & 4.0 & 2.3 & 11.3 & 79.4 & 3.5 & 3.1 & 14.0 \\
\hline Why does the person feel this way?* & 46.3 & 2.8 & 8.5 & 42.4 & 40.3 & 3.5 & 2.3 & 53.9 \\
\hline
\end{tabular}

AR $(n=177)$ and PS $(n=258)$. Category values are expressed in percentage. $* p<0.05$.

or without milk), balm mint (Melissa sp), pumpkin seeds, creosote with milk, vinegar, cat's claw (Uncaria sp), eggplant, and water with salt.

Regarding preventive measures, more than half of the AR respondents (64.4\%) and just a third from PS $(28.3 \%)$ declared taking any action to avoid intestinal parasites. The most common preventions were use of shoes $(\mathrm{AR}=31.6 \%$, $\mathrm{PS}=61.6 \%)$, washing food $(\mathrm{AR}=40.4 \%, \mathrm{PS}=47.9 \%)$, and drinking treated water $(\mathrm{AR}=21.9 \%, \mathrm{PS}=30.1 \%)$; some families reported the utilization of medicines and abstinence of candy consumption. Other responses referring to intestinal parasite infection are presented in Table 5.

The overall prevalence $(95 \% \mathrm{CI})$ of the IPIs was $49.7 \%$ (i.e., 157 positive out of 316 ) and $27.2 \%$ (i.e., 102 positive out of 375) for PS and AR, respectively (Tables 6 and 7). The percentage of positive samples that contained a single parasite was $53.5 \%$ in PS and $96.1 \%$ in AR (Table 6). There was no relationship between IPIs and gender. The age groups with the greatest number of positive samples were children ( 0 to 9 years, i.e., 59 of 93 samples) and adults ( $\geq 20$ years, i.e., 59 of 146 samples) in PS, where in AR, the highest numbers were in adults (i.e., 58 of 222 samples) (Table 7).

The protozoan intestinal infections were more common than helminths in both communities, 44.1 (CI 95\% 38.749.5) vs. 15.2 (CI 95\% 11.6-19.5) in PS and 25.3 (CI 95\% 20.9-29.7) vs. 1.9 (CI 95\% 0.5-3.2) in AR (Table 7). The prevalence of these IPIs was two and a half times greater in the 0-to-9-year age group in PS when compared to AR, and this difference was statistically significant for this age group of these communities $(p=0.039)$. Moreover, the prevalence of IPIs by helminths in PS was eight times greater than in AR, and in the 10-to-19 age group, nine times greater. However, within the PS age groups, these infections were most common in the 0-to-9-year-old children $(p<0.001)$ (Table 7).

In this study, we detected in stool samples the protozoan E. histolytica, Entamoeba coli, G. lamblia, and Iodamoeba butschlli and the helminths A. lumbricoides, T. trichiura, Strongyloides stercoralis, Enterobius vermicularis, Hymenolepis nana, Ancylostoma duodenale, and Taenia spp. The most frequent association among the parasites was $E$. histolytica with E. coli, apparent in PS samples. In addition, in $15.5 \%$ of the positive samples for G. lamblia in PS, coinfection with $A$. lumbricoides was also observed, probably due to the common environmental factors that may affect their transmission. In contrast, in AR, mixed infections were present in few positive samples, the most frequent being $E$. coli with $G$. lamblia.

The most frequent parasite association in PS samples was E. histolytica with $E$. coli in $16.5 \%$ of the positive samples (26 of 157). In addition, in $15.5 \%$ of the $G$. lamblia-positive samples from PS (12 of 77), there was also coinfection with $A$. lumbricoides. In AR, mixed infections were present in few positive samples, the most frequent being $E$. coli with $G$. lamblia (in 3 of 102). Table 8 compares the quantitative analysis of answers to the questions about KAP and the frequency of IPIs of respondents in the communities studied. There was no 
Table 5 Frequency of the multiple answers to the questionnaire on knowledge of inhabitants of AR and PS communities located in Travessão District, Campos dos Goytacazes, Rio de Janeiro, Brazil, concerning some aspects related to importance and preventive care

$\operatorname{AR}(n=177)$ and PS $(n=258)$.

Are worms bad for people?

Is it important not to contract worms?

\begin{tabular}{|c|c|c|c|c|c|}
\hline \multirow{2}{*}{ Questions } & \multirow[t]{2}{*}{ Why } & \multicolumn{2}{|l|}{ AR } & \multicolumn{2}{|l|}{ PS } \\
\hline & & $n$ & $\%$ & $n$ & $\%$ \\
\hline \multirow[t]{8}{*}{ Do worms cause problems for people? } & Yes & 172 & 97.2 & 248 & 96.1 \\
\hline & Don't know & 54 & 31.4 & 157 & 63.3 \\
\hline & Due to symptoms & 57 & 33.1 & 28 & 11.3 \\
\hline & Lead to death & 12 & 7.0 & 11 & 4.4 \\
\hline & It's a disease & 8 & 4.7 & 11 & 4.4 \\
\hline & Other ways & 41 & 23.8 & 51 & 20.7 \\
\hline & No & 5 & 2.8 & 10 & 3.9 \\
\hline & Don't know & 5 & 100.0 & 10 & 100.0 \\
\hline \multirow[t]{10}{*}{ Are worms bad for people? } & Yes & 167 & 94.4 & 245 & 95.0 \\
\hline & Don't know & 40 & 24.0 & 137 & 55.9 \\
\hline & Due to symptoms & 36 & 21.6 & 29 & 11.8 \\
\hline & Lead to death & 15 & 9.0 & 21 & 8.6 \\
\hline & It's a disease & 21 & 12.6 & 19 & 7.8 \\
\hline & Other ways & 55 & 32.9 & 39 & 15.9 \\
\hline & No & 10 & 5.6 & 13 & 5.0 \\
\hline & Don't know & 4 & 40.0 & 9 & 69.2 \\
\hline & The cure exists & 5 & 50.0 & - & - \\
\hline & There are worse diseases & 1 & 10.0 & - & - \\
\hline \multirow[t]{8}{*}{ Is it important not to contract worms? } & Yes & 176 & 99.4 & 249 & 96.5 \\
\hline & Don't know & 32 & 18.2 & 111 & 44.6 \\
\hline & It is harmful to health & 61 & 34.7 & 43 & 17.3 \\
\hline & It's a disease & 31 & 17.6 & 20 & 8.0 \\
\hline & It's preferable to avoid & 9 & 5.1 & 22 & 8.8 \\
\hline & Other ways & 43 & 24.4 & 52 & 20.9 \\
\hline & No & 1 & 0.6 & 9 & 3.5 \\
\hline & Don't know & 1 & 100.0 & 9 & 100.0 \\
\hline
\end{tabular}

correlation between these data, except in the question "What causes IPIs?" in AR $(p=0,027)$.

\section{Discussion}

In this study, we assessed the KAP related to IPIs among residents of two low-income communities of the Travessão
District area, Campos dos Goytacazes, RJ, Brazil, and investigated whether there was a correlation between these features and IPI prevalence. Water analysis confirmed that all underground water of this area was highly contaminated. Thus, despite some families with better economic conditions being able to consume industrialized mineral water, most families in both communities drink either inappropriate water for consumption from superficial wells or treated
Table 6 Prevalence of IPIs in inhabitants of AR and PS communities located in Travessão District, Campos dos Goytacazes, Rio de Janeiro, Brazil

${ }^{*} p<0.001$

${ }^{\mathrm{a}} \mathrm{PR}(95 \% \mathrm{CI})=1.83(1.50-2.23)$

\begin{tabular}{|c|c|c|c|c|}
\hline \multirow[t]{2}{*}{ Characteristic } & \multicolumn{2}{|l|}{$\mathrm{AR}$} & \multicolumn{2}{|l|}{ PS } \\
\hline & $n$ & $\%(95 \% \mathrm{CI})$ & $n$ & $\%(95 \% \mathrm{CI})$ \\
\hline IPIs* a & 102 & $27.2(22.7$ to 31.7$)$ & 157 & $49.7(44.1$ to 55.1$)$ \\
\hline Monoparasitism* & 98 & 96.1 (92.3 to 99.9$)$ & 84 & 53.5 (42.8 to 64.2$)$ \\
\hline \multicolumn{5}{|l|}{ Polyparasitism } \\
\hline 2 & 4 & $3.9(0.1$ to 7.7$)$ & 52 & 33.1 (20.3 to 45.9$)$ \\
\hline 3 & - & - & 15 & $9.6(-5.3$ to 24.5$)$ \\
\hline 4 & - & - & 4 & $2.5(-12.8$ to 17.8$)$ \\
\hline 5 & - & - & 2 & $1.3(-14.4$ to 17.0$)$ \\
\hline
\end{tabular}




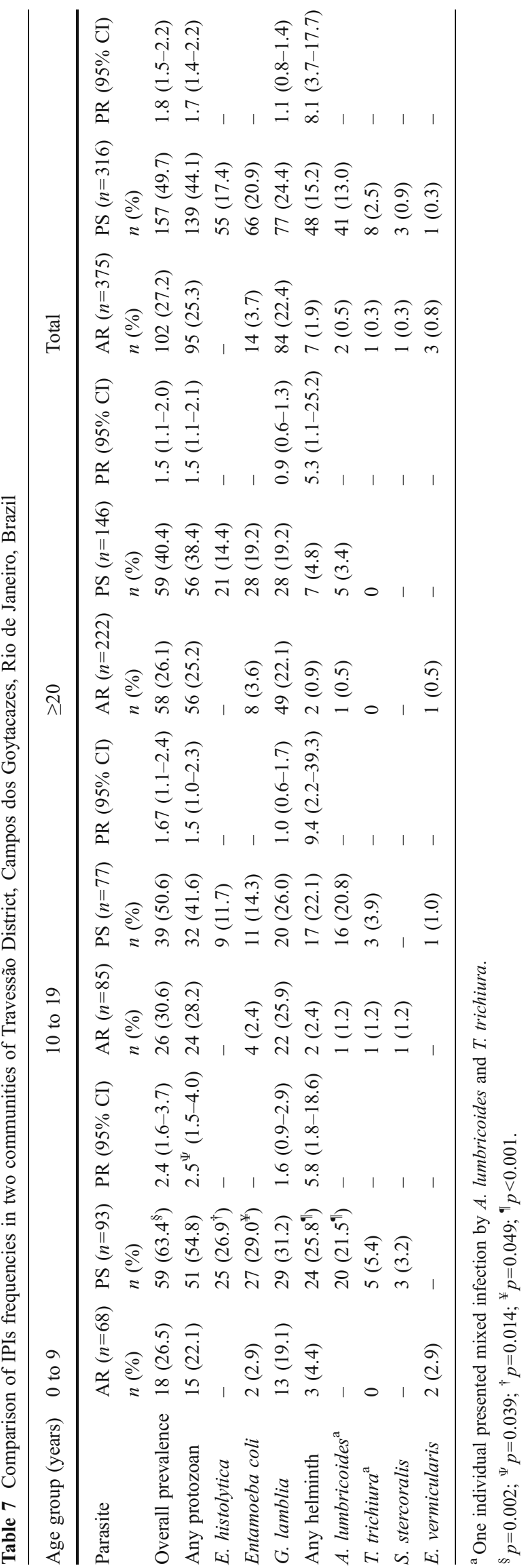

Table 8 Comparison between the quantitative analysis of answers to the questions about KAP and frequency (\%) of IPIs in respondents of two communities of Travessão District, Campos dos Goytacazes, Rio de Janeiro, Brazil

\begin{tabular}{|c|c|c|c|c|}
\hline \multirow[t]{2}{*}{ Questions } & \multicolumn{2}{|c|}{$\operatorname{AR}(n=79)$} & \multicolumn{2}{|c|}{ PS $(n=56)$} \\
\hline & $n$ & $\%$ IPIs & $n$ & $\%$ IPIs \\
\hline \multicolumn{5}{|c|}{ What do you know about IPIs? } \\
\hline Correct & 58 & 19.0 & 21 & 42.9 \\
\hline Wrong or unknown & 21 & 19.0 & 35 & 48.6 \\
\hline \multicolumn{5}{|l|}{ What causes IPIs? ${ }^{\mathrm{a}}$} \\
\hline Correct & 36 & $8.3^{*}$ & 17 & 29.4 \\
\hline Wrong or unknown & 43 & 27.9 & 39 & 53.8 \\
\hline \multicolumn{5}{|c|}{ How do you acquire IPIs? } \\
\hline Correct & 50 & 20.0 & 31 & 51.6 \\
\hline Wrong or unknown & 29 & 17.2 & 25 & 40.0 \\
\hline \multicolumn{5}{|c|}{ Where do you acquire IPIs? } \\
\hline Correct & 38 & 18.4 & 24 & 45.8 \\
\hline Wrong or unknown & 41 & 19.5 & 32 & 46.9 \\
\hline \multicolumn{5}{|c|}{ How do intestinal parasites infect human beings? } \\
\hline Correct & 47 & 17.0 & 24 & 50.0 \\
\hline Wrong or unknown & 32 & 21.9 & 32 & 43.8 \\
\hline \multicolumn{5}{|c|}{ Where do intestinal parasites lodge after infection? } \\
\hline Correct & 63 & 19.0 & 45 & 51.1 \\
\hline Wrong or unknown & 16 & 18.8 & 11 & 27.3 \\
\hline \multicolumn{5}{|c|}{ How long do intestinal parasites survive in the body? } \\
\hline Correct & 58 & 17.2 & 37 & 48.6 \\
\hline Wrong or unknown & 21 & 23.8 & 19 & 42.1 \\
\hline \multicolumn{5}{|c|}{ What happens with the intestinal parasites out of the body? } \\
\hline Correct & 38 & 21.1 & 21 & 42.9 \\
\hline Wrong or unknown & 41 & 17.1 & 35 & 48.6 \\
\hline
\end{tabular}

water transported by trucks supplied by the city hall, which is not sufficient for the community needs, hence being supplemented with contaminated ground water from domestic wells. In our results (Table 2), we determined a high contribution of fecal contamination in well water, probably because of the inadequate sanitation, with sewage dispensed directly in the soil in some points and visible leakage together with inadequate, negligent routine maintenance in some septic tank systems. This certainly contributes for dissemination of diseases caused by parasites, presenting a fecal-oral transmission route.

The dwellings of the AR community presented the better conditions, and their inhabitants had social and educational levels better than those from PS, probably due to a greater per-capita income. Besides, in PS, the streets are unpaved, there are several animals roaming the streets, and a sugar cane plantation close to the houses serves as a deposit for 
resident garbage despite the regular municipal government garbage collection (Fig. 2). Such living conditions readily facilitated soil contamination by human and animal feces, infiltrating the superficial wells of freshwater, consumed mainly without any treatment by the residents and verified by us as highly contaminated (Table 2). Based on our results from socioeconomic data (Table 1) and field observations in these communities, we verified that the environmental variables associated with a low-income level and lack of education resulted in a population with not only scant resources but also a high likelihood of IPI transmission.

Previous studies correlated the prevalence of IPIs with KAP (Mehraj et al. 2008; Curtale et al. 1998; Mello et al. 1988). Questionnaire analysis of both communities revealed that the residents had a special codification to denominate intestinal parasites. The analysis related to aspects of parasite biology, interesting for epidemiological studies (Rey 2002), indicates that the respondents from both communities presented reasonably correct knowledge about the matter (Tables 3 and 4). Most answered appropriately in relation to infection sources and gateway of parasites (barefoot, unwashed food, contaminated water, lack of hygiene and sanitation); however, some individuals associated the ingestion of sweets as a possible source of infection, which was a wrong concept strongly sedimented in popular culture. Nevertheless, the "habitat" of the parasites in man was indicated correctly, even though they did not know all the migration of the worms in the human body, as well as the stages of development and reproduction (evolutionary cycle). Most of the respondents did not know the disposal routes, although some correctly answered that it was by feces. Many were unable to identify the infective form for man (cysts, eggs, and/or larvae). In addition, they were not able to relate the elimination of parasites with environmental contamination and transmission of intestinal parasites. In particular, there was great confusion and contradiction by the respondents from both communities concerning their knowledge on transmission mechanisms.

The respondents of the AR community demonstrated better knowledge in relation to most of the issues concerning IPIs $(p<0.05)$, which was maintained with respect to the other categories (Table 4). In accordance with Mehraj et al. (2008) and Mello et al. (1988), this fact can be related to the educational level of the respondents and ease of access to information sources. It is also probable that children transfer the knowledge acquired in the school to their parents.

Regarding the importance of IPIs for the residents, in both communities, most respondents affirmed that IPIs cause health problems that are associated to several symptoms. They said that although IPIs are diseases that may lead to death, worse illnesses exist. In contrast, other respondents did not recognize the due importance because they believe that IPIs are curable as are "normal diseases" and that more serious diseases deserve attention. These results are in agreement with Gazzinelli et al. (2002), where the respondents affirm that cardiovascular diseases are more important than IPIs.

High prevalence of IPIs has been consistently reported in a number of studies conducted in similar populations (Barçante et al. 2008; Silva and Santos 2001; Gamboa et al. 1998). Our results show that the overall prevalence of IPIs in PS (49.7\%) was greater than in AR (27.2\%), as well as the cases of polyparasitism and parasite diversity (Tables 6 and 7). The age groups more infected were children ( 0 to 9 years) and adults ( $\geq 20$ years) in PS. The adult group was also more affected in AR (Table 7). This can be explained by complex interactions between hosts, parasites, and environment, that is, by environmental variables (conditions of homes and sanitation) as much as by habits of residents, in the case of adults of both communities. The prevalence of IPIs in children can be justified because they are more immunologically susceptible to the development of these infections, aggravated by habits determining reinfection occurrence (Silva and Santos 2001). In addition, in the PS community, a high degree of peridomiciliary and domiciliary environmental contamination prevails, resulting from the precarious living conditions of the inhabitants, which increases exposure and transmission of intestinal parasites.

Except for the question "What causes IPIs?" we observed that there was no correlation between KAP and the frequency of IPIs of respondents in the communities studied. Our findings are justified by the fact that not always does the knowledge of the respondents reflect their habits (attitudes and practices) (WHO 2006b). This is aggravated by the impossibility of change in the environmental conditions for the inhabitants of the communities, which do not have the resources and support of the state authorities. On the other hand, there is a misunderstanding on the part of the residents that most IPIs are asymptomatic, and therefore, individuals require access to medical care and an effective policy of IPI control.

In agreement with the National Plan of Environmental Health in Brazil, the Unified Health System must promote the necessary adaptations for the improvement of basic health attention regarding specialized medical assistance, privileging disease prevention, and control as well as health promotion. There has been flagrant negligence in Brazil in this sphere of public health administration, mainly regarding poor communities, where intestinal parasite transmission assumes alarming proportions. These data reflect incongruities in the National Plan of Surveillance and Control of Enteroparasitosis (NPSCE), in the extent 
of the Bureau of Sanitary Surveillance (Ministry of Health), where the national and regional indexes stay based in estimates.

NPSCE (SVS 2005) stipulates that "within is established the use of information about prevalence, morbidity and mortality caused or associated to parasitic infections, generating analytical studies drawn from the epidemic evaluation of the registered data, and it strives for the definition of strategies for the control of the enteroparasitosis. NPSCE should be instituted and constituted, respecting the competence areas and government levels, for the organs that develop activities of Epidemic, Sanitary and Environmental Surveillance, Sanitation, Health Education, Diagnosis and Attendance." We note that there is an asynchrony between the government levels and a total ignorance of the real indexes of prevalence and morbidity by the public administrators as well as the population about control and prevention measures.

On the other hand, in Brazil, there is the pressing need for the teaching of parasitology to be reviewed by medical area careers, in universities, where there is a compartmentalization of the contents that are not integrated in the country's social reality. The knowledge requires recycling, and the excessive number of theoretical classes is detrimental, sacrificing practice, which lessens the teachinglearning process quality.

Innovative educational practices bringing science and art to the classroom have been producing exciting results, starting from student-teacher participation to engagement of the entire school administration towards disease prevention (Japiassu 1988). These practices should be better explored and stimulated in the educational environment once the "Health at School Program" (MEC 2004) of the Brazilian Federal Government, instituted by presidential ordinance no. 6.286, December 5, 2007, foresees an intersectorial policy between the Ministries of Health and Education with the prospect to integrate health attention (prevention, promotion, and basic attention) with the participation of family health teams (Health of the Family Program) among the children and adolescents of public schools (preschool, elementary, and high school education) as well as young adult and adult education and professional and technical schools.

In conclusion, the transmission and prevalence of intestinal parasites in low-income communities of Campos dos Goytacazes, RJ, Brazil, is probably associated with a combination of multiple and complex factors that determine the interaction between the parasite, the host, and the environment. These factors are worsened by social determinants that could be minimized by the adoption of prophylactic measures recognized and accepted by residents and authorities for the interruption of IPI transmission.
Our results encourage new studies in the area, evaluating the impact of prophylactic and educational measures in health, together with the awareness of public authorities to promote improvements in sanitation conditions and in homes, as well as wide range medical care access. We believe that these efforts will greatly contribute to the prevention and reduction of IPIs in communities with similar characteristics to those presented herein.

Acknowledgments We are very grateful to the administrative staff of the Centro de Biociências e Biotecnologia, Universidade Estadual do Norte Fluminense Darcy Ribeiro, UENF; to Coordinator Prof. Christovam Cardoso and to the Nursing Course students of the Universidade Salgado de Oliveira, UNIVERSO, Campos dos Goytacazes, for the participation in the data collection of the residents of the communities; to Dr. José Carlos Mendonça of the Laboratório de Engenharia Agrícola-LEAG/CCTA/UENF for the climatic data from PESAGRO weather station, Campos dos Goytacazes, RJ; to Dr. Sérgio Luís de Andrade Peixoto, Dr. Raquel Montesano de Carvalho, Dr. Camila Ribeiro Lantiman, and the technical staff from the Hospital de Travessão; to Dr. José Manuel Moreira, Director of Fundação Dr João Barcellos Martins; to Luciana Cordeiro de Araújo and the technical staff from Laboratório Regional de Patologia Clínica, Hospital Geral de Guarús, Fundação Dr. Geraldo da Silva Venâncio and to the technical staff of the Laboratório de Análises Clínicas Plínio Bacelar for making the clinical and laboratorial examinations of individuals possible; to Ms. Elizabeth Tudesco Costa Tinoco from the Epidemiology Division of Municipal Secretariat of Health for the operational support; to Dr. Eduardo Costa, Director of Farmanguinhos, FIOCRUZ, for the antiparasitaires drug donation used in the treatment of infected individuals; to Drs. Fátima Cecchetto, Otávio Sarmento Pieri, and Renato Augusto Damatta for the critical revision of the manuscript and for the English review and revision by Mitchell Raymond Lishon, native of Chicago, IL, USA (UCLA 1969).

\section{References}

APHA, American Public Heath Association (1998) Standard methods for the examination of water and wastewater. CLESCERI, Washington, D.C

Barçante TA, Cavalcanti DV, Silva GAV, Lopes PB, Barros RF, Ribeiro GP, Neubert LF, Barçante JMP (2008) Enteroparasitos em crianças matriculadas em creches públicas do Município de Vespasiano, Minas Gerais. Rev Patol Trop 37:33-42

Bencke A, Artuso GL, Reis RS, Barbieri NL, Rott MB (2006) Enteroparasitoses em escolares residentes na periferia de Porto Alegre, RS, Brasil. Rev Patol Trop 35:31-36

Bethony J, Brooker S, Albonico M, Geiger SM, Loukas A, Diemert D, Hotez PJ (2006) Soiltransmitted helminth infections: ascariasis, trichuriasis, and hookworm. Lancet 367:1521-1532

Bóia MN, Carvalho-Costa FA, Sodré FC, Eyer-Silva WA, Lamas CC, Lyra MR, Pinto VL Jr, Cantalice Filho JP, Oliveira ALL, Carvalho LMA, Gross JB, ALS Souza, Moraes TI, BermudezAza EH, EB Martins, Coura JR (2006) Mass treatment for intestinal helminthiasis control in an Amazonian endemic area in Brazil. Rev Inst Med Trop S Paulo 48:189-195

CDC (2006) DPDx: laboratory identification of parasites of public health concern. Center for Disease Control \& Prevention, USA, Atlanta

Costa NA, Alves MG (2007) Potencial de uso e ocupação urbana do solo no município de Campos dos Goytacazes, RJ, utilizando 
mapeamento geológico-geotécnico e técnicas de geoprocessamento. Rev Bras Cartogr 1:23-32

Curtale F, Pezzotti P, Sharbini AL, Al Madat H, Ingrosso P, Saad YS, Babille M (1998) Knowledge, perceptions and behaviour of mothers toward intestinal helminths in Upper Egypt: implications for control. Health Policy Plan 13:423-432

Dagci H, Kurt Ö, Demirel M, Östan I, Azizi NR, Mandiracioglu A, Yurdagül C, Tanyüksel M, Eroglu E, Ak M (2008) The prevalence of intestinal parasites in the province of Izmir, Turkey. Parasitol Res 103:839-845

Ferreira GR, Andrade CFS (2005) Some socioeconomic aspects related to intestinal parasitosis and evaluation of an educational intervention in scholars from Estiva Gerbi, SP. Rev Soc Bras Med Trop 38:402-405

Gamboa MI, Basualdo JA, Kozubsky L, Costas E, Cueto Rua E, Lahitte HB (1998) Prevalence of intestinal parasitosis within three population groups in La Plata, Argentina. Eur J Epidemiol 14:55-61

Garg R, Lee LA, Beach MJ, Wamae CN, Ramakrishnan U, Deming MS (2002) Evaluation of the Integrated Management of Childhood Illness guidelines for treatment of intestinal helminth infections among sick children aged 2-4 years in western Kenya. Trans R Soc Trop Med Hyg 96:543-548

Gazzinelli MF, Gazzinelli A, Santos RV, Gonçalves LAO (2002) A interdição da doença: uma construção cultural da Esquistossomose em área endêmica, Minas Gerais, Brasil. Cad Saude Publica 18:1629-1638

Japiassu ROV (1988) Jogos teatrais na escola pública. Rev Fac Educ 24:81-97

Keiser J, Utzinger J (2008) Efficacy of current drugs against soiltransmitted helminth infections: systematic review and metaanalysis. JAMA 299:1937-1948

Kucik CJ, Martin GL, Sortor BV (2004) Common intestinal parasites. Am Fam Physician 69:1161-1168

Lutz A (1919) O Schistosoma mansoni e a schistosomatose segundo observações feitas no Brasil. Mem Inst Oswaldo Cruz 11:121-155

Mascie-Taylor CG, Karim R, Karim E, Akhtar S, Ahmed T, Montanari RM (2003) The cost-effectiveness of health education in improving knowledge and awareness about intestinal parasites in rural Bangladesh. Econ Hum Biol 1:321-330

MEC (2004). Orientações sobre o Programa Saúde na Escola para a elaboração dos projetos locais. (Ministério da Educação e Cultura). http://dtr2004.saude.gov.br/dab/docs/geral/orientacoes_pse.pdf. Accessed 10 August 2009

Mehraj V, Hatcher J, Akhtar S, Rafique G, Beg MA (2008) Prevalence and factors associated with intestinal parasitic infection among children in an urban slum of Karachi. PLoS ONE 3:1-6

Mello DA, Pripas S, Fucci M, Santoro MC, Pedrazani ES (1988) Helmintoses intestinais: conhecimentos, atitudes e percepção da população. Rev Saúde Publica 22:140-149
Minenoa T, Avery MA (2003) Giardiasis: recent progress in chemotherapy and drug development. Curr Pharm Des 9:841-855

Montresor A, Crompton DWT, Gyorkos TW, Savioli L (2002) Helminth control in school-age children. A guide for managers of control programmes. World Health Organization, Geneva

MS, Ministério da Saúde, Brasil (2004) - Portaria MS 518/2004

Omoigberale AI, Airauhi LU (2006) Aspects of the epidemiology of intestinal parasitoses (IP) in children: knowledge, practices and perceptions of mothers. Niger J Clin Pract 9:109-113

Pillai DR, Kain KC (2003) Common intestinal parasites. Curr Treat Options Infect Dis 5:207-217

Reed SL (2001) Amebiasis and infection with free-living amebas. In: Braunwald E, Fauci AS, Kasper DL, Hauser SL, Longo DL, Jameson JL (eds) Harrison's principles of internal medicine, 17th edn. McGraw-Hill, New York, pp 1199-1202, Section 18202

Rey L (2002) Bases da Parasitologia Médica. Guanabara Koogan, São Paulo

Silva CG, Santos HA (2001) Ocorrência de parasitoses intestinais da área de abrangência do Centro de Saúde Cícero Idelfonso da regional oeste da prefeitura municipal de Belo Horizonte, Minas Gerais. Rev Biol Cien Terra 1:1-11

Stephenson LS, Latham MC, Ottesen EA (2000) Malnutrition and parasitic helminth infections. Parasitology 121(Suppl):S23-S38

SVS (2005) Plano nacional de vigilância e controle das enteroparasitoses. Secretaria de Vigilância em Saúde, Ministério da Saúde, Brasília, DF, Brasil

Uchôa CMA, Serra CMB, Magalhães CM, Silva RMM, Figliuolo LP, Leal CA, Madeira MF (2004) Educação em saúde: ensinando sobre a leishmaniose tegumentar Americana. Cad Saúde Publica 20:935-941

WHO (2004) Water, sanitation and hygiene links to health: facts and figures. World Heath Organization, Geneva

WHO (2005a) Deworming for health and development. Report of the third global meeting of the partners for parasite control. World Heath Organization, Geneva

WHO (2005b) Urbani school health kit teacher's resource book. A lively and healthy me Urbani School Health Kit-teacher's resource book a campaign on preventing and controlling worm infections for health promoting schools. World Health Organization, Geneva

WHO (2006a) Guidelines for drinking-water quality: incorporating first addendum. Recommendations. World Health Organization, Geneva

WHO (2006b) Bridging the "Know-Do" gap meeting on knowledge translation in global health. World Health Organization, Geneva

WHO (2009) Elimination of neglected diseases and other povertyrelated infections. The 49th Directing Council at the 61st Session of The Regional Committee. Provisional Agenda Item 4.5. World Heath Organization, Geneva

www.ibge.gov.br. Accessed 30 May 2009 